\title{
Identidades, práticas discursivas e os estudos organizacionais: Uma proposta teórico-metodológica
}

\author{
Identities, discursive practices and organizational studies: A theoretical-methodological \\ proposal
}

Mariana Mayumi Pereira de Souza ${ }^{1}$
Alexandre de Pádua Carrieri $^{2}$

\section{Resumo}

O objetivo do presente artigo é propor uma visão da identidade nos estudos organizacionais que integre as ideias: da identidade como prática cotidiana; da prática como prática discursiva; e da prática discursiva pautada por racionalidades. As práticas pautadas pelas diferentes racionalidades permitem ao indivíduo exercer uma identidade autêntica ou instrumental em seu cotidiano. Aplicando-se tal entendimento ao contexto das organizações, salienta-se a importância de se estudar os indivíduos em relação aos níveis coletivos, pois, segundo a teoria da delimitação dos sistemas sociais de Ramos (1981), em diferentes enclaves da vida social, torna-se possível ao indivíduo exercer diferentes tipos de racionalidade. Em contrapartida, segundo o conceito de identidade metamorfose de Ciampa (2003), defende-se também a ideia de que o indivíduo é capaz de exercer uma identidade autêntica em contextos pautados pela instrumentalidade, sendo capaz de transformar-se e transformar as condições que o reprimem. Cabe, portanto, ao pesquisador, identificar os grupos, ou identidades coletivas, que emergem no contexto das organizações e analisar a relação entre as racionalidades coletivas e individuais envolvidas, para que, ao final, sejam desvendadas as identidades em jogo. O artigo apresenta primeiramente a articulação teórica de sua proposta e, em seguida, indica caminhos metodológicos possíveis para sua operacionalização.

Palavras-chave: Identidade. Prática discursiva. Racionalidade. Identidade coletiva. Análise do discurso.

\begin{abstract}
This paper aims to propose a perspective on identity in organizational studies, considering an integrative view of identity as everyday practices, practices as discursive practices, and discursive practices as oriented by rationalities. Oriented by different rationalities, individuals are capable of practicing either an authentic or an instrumental identity in their current lives. Applying this assertion to organizational contexts, we emphasize the importance of studying individuals in relation to collective levels. According to Ramos' (1981) theory on the delimitation of social systems, in different worlds of social life, individuals are allowed to act according to different rationality types. On the other hand, considering Ciampa's (2003) concept of metamorphosis identity, we can also state that individuals are capable of practicing an authentic identity in instrumental-oriented contexts. In this way, they transform themselves and transform repressive conditions. Therefore, researchers willing to comprehend identity processes in organizational contexts are expected to identify emergent groups, i.e. collective identities, and then analyze the relationship between collective and individual rationalities in order to reveal identity construction. This paper presents a theoretical articulation of our proposal and, in the final part, indicates possible methodological paths to operationalizing it.
\end{abstract}

Keywords: Identity. Discursive practice. Rationality. Collective identity. Discourse analysis.

Artigo submetido em 26 de julho de 2010 e aceito para publicação em 22 de março de 2011.

1 Mestre em Administração pela Universidade Federal de Minas Gerais; Professora e Coordenadora do Curso de Administração na Universidade Federal de Viçosa - Campus Florestal; Membro do Núcleo de Estudos Organizacionais e Sociedade (NEOS). Endereço: Rua Elói Mendes, 371, Sagrada Família, CEP 31030-110, Belo Horizonte - MG, Brasil. E-mail: mariana.mayumi@ufv.br

2 Doutor em Administração pela Universidade Federal de Minas Gerais; Professor Adjunto pela Universidade Federal de Minas Gerais; Coordenador do Núcleo de Estudos Organizacionais e Sociedade (NEOS). Endereço: Av. Antônio Carlos, 6627, Pampulha / Faculdade de Ciências Econômicas - sala 4072, CEP 31270-901, Belo Horizonte - MG, Brasil. E-mail: alexandre@cepead.face.ufmg.br 


\section{Introdução}

O objetivo deste artigo é contribuir para o debate entre pesquisadores que se interessam pelo estudo da identidade de indivíduos e grupos no contexto das organizações. Para isso, primeiramente, propõe-se ao pesquisador ir além da dualidade entre identidade pessoal e social, entendida como artificial e, muitas vezes, limitadora da capacidade de ação dos sujeitos. Apresentam-se as noções da identidade como prática e, em seguida, argumenta-se que tais práticas somente podem ser acessadas pelo pesquisador enquanto práticas discursivas. $\mathrm{O}$ presente artigo se baseia na corrente paradigmática da identidade autônoma, entendendo o indivíduo como um ser integral, que se revela enquanto sujeito de sua ação (e de sua identidade) em sua prática cotidiana. A partir de tal concepção, percebeu-se a necessidade de uma proposta que desenvolvesse e operacionalizasse a pesquisa sobre identidade no contexto organizacional, mantendo-se coerência com posicionamentos ontológicos e epistemológicos. Adicionalmente, entende-se que as práticas são pautadas por diferentes racionalidades que conduzem o indivíduo a exercer uma identidade autêntica ou instrumental em seu cotidiano. Aplicando-se a proposta ao contexto das organizações, salienta-se a importância de se estudar os indivíduos em relação aos níveis coletivos. Por fim, busca-se demonstrar caminhos possíveis para se pensar a operacionalização de pesquisas segundo o arcabouço teórico-empírico proposto.

Identidade é uma palavra originária da lógica, álgebra e filosofia clássica, que se estendeu por diferentes campos científicos e escolas de pensamento, ganhando novos significados. A palavra é derivada dos vocábulos latinos idem e identitas, que significam "o mesmo", e entitas, que significa "entidade" (CALDAS e WOOD JR., 1997). Embora a utilização popular do termo denote sentido de permanência, uniformidade e continuidade, em sua origem filosófica, o conceito de identidade se refere à propriedade de algo ser idêntico a si mesmo, se diferenciando automaticamente dos demais. Essa definição não presume que o indivíduo portador de identidade mantenha coerência comportamental ao longo do tempo e se distinga dos demais por características especiais. A pessoa seria considerada como idêntica a si mesma, detendo sempre, portanto, uma identidade (CIAMPA, 2005).

Entretanto, no pensamento tradicional ocidental, o simples fato de ser humano significa que se possui um self (si-mesmo), ou seja, uma identidade com conotação de singularidade e distinção que persiste no tempo. Considera-se, além disso, que a identidade pessoal seria imutável e interior ao indivíduo. Para Ciampa (2005), a maioria das pessoas tende a entender a identidade como algo dado, como se, uma vez identificado o indivíduo, a produção de sua identidade tivesse se esgotado como produto. Tal concepção da identidade finda por torná-la um conceito essencialmente idealista, algo a ser perseguido pelos indivíduos, como se eles não fossem dotados de uma identidade no seu fazer cotidiano. Dessa forma, muito se tem discutido sobre o que seria a identidade, como ela se constrói e como se autodefinir.

A importância conferida à noção de identidade, tanto na vida prática, quanto no discurso científico, fez com que, ao longo do tempo, o conceito fosse abordado e apropriado pelas várias ciências sociais e humanas: psicanálise, psicologia, sociologia, antropologia e, mais recentemente, estudos organizacionais, resultando numa ampla utilização, aplicação e falta de consenso. A variedade de definições e formas de construção da identidade reflete as mudanças de concepção do ser humano enquanto sujeito ao longo da História e, consequentemente, as mudanças na ordem social. A perspectiva da identidade tem se modificado, de núcleo autônomo, permanente e constante, para uma perspectiva dinâmica, de processo em construção (CALDAS e WOOD JR., 1997; HALL, 2003).

Os estudos sobre identidade nas organizações refletem a diversidade de perspectivas e paradigmas das demais áreas. Albert e Whetten (1985) são considerados pioneiros nos estudos de analogia entre a identidade individual e a organizacional. Segundo os autores, as organizações, assim como os indivíduos, também possuiriam um caráter central, uma identidade. Esta última compreenderia as crenças partilhadas pelos indivíduos sobre o que é central, distintivo e duradouro na organização. Esses três critérios seriam suficientes para se definir identidade organizacional como conceito científico. 
Contudo, ao longo dos anos, estudos sobre a identidade ganharam adeptos de diferentes correntes epistemológicas. Investiga-se a identidade em diversos níveis, perspectivas e objetivos (CALDAS e WOOD JR, 1997). Carrieri, Paula e Davel (2008) identificaram três formas de se conceber a identidade em estudos organizacionais: múltipla, fluida ou autônoma. A identidade múltipla propõe a identidade como construto complexo, multifacetado e sujeito a contingências ambientais e temporais. Essa concepção se baseia em estudos sobre diversidade organizacional e sobre representações sociais. Já a visão fluida da identidade a concebe como uma realização social, como produto em perpétuo processo de reajuste, reconstrução e renegociação. Essa visão se fundamenta em estudos que questionam a solidez de objetos organizacionais e também em estudos sobre narrativas nas organizações. Por fim, a ideia da identidade autônoma propõe que o indivíduo deva conseguir transcender o desempenho de papéis organizacionais, preservando sua capacidade de existir como sujeito. Essa ideia traz contribuições da psicologia social e da teoria crítica, focando a subjetividade e a história de vida dos indivíduos (CARRIERI, PAULA e DAVEL, 2008).

Este artigo divide-se em cinco seções, sendo a primeira esta introdução. Na seção a seguir, propõe-se a visão da identidade enquanto prática, a partir da negação de visões dualistas e estáticas desse conceito. Ainda nessa seção, são apresentadas as definições que se propõe aplicar ao conceito de prática. No terceiro item, conceitos sobre racionalidade são discutidos de forma mais aprofundada. Tais conceitos fundamentam a distinção teórica entre identidade instrumental e identidade substancial. A quarta seção busca aplicar as ideias desenvolvidas à noção de identidade coletiva e aos estudos sobre identidade em organizações. Finalmente, na quinta parte do artigo apresenta-se uma proposta para se realizar a análise de identidades em contextos organizacionais, buscando demonstrar a possibilidade de se integrar os conceitos de identidade, prática, discurso e racionalidade em pesquisas empíricas.

\section{Para além da Dualidade entre Identidade Pessoal e Social: Entendendo a Identidade como Prática}

Ao analisar o processo de construção da identidade, deve-se levar em conta tanto a perspectiva pessoal quanto a social. Para obter uma visão coerente e dinâmica, que considere tanto a importância da subjetividade quanto as determinações externas, é necessário um esforço em congregar uma visão da identidade que integre a perspectiva social e pessoal da identidade, conforme proposto por Dubar (2005, p. 136):

[...] identidade nada mais é que o resultado a um só tempo estável e provisório, individual e coletivo, subjetivo e objetivo, biográfico e estrutural, dos diversos processos de socialização que, conjuntamente, constroem os indivíduos e definem as instituições.

A identidade-para-si e para o outro são constructos inseparáveis que vão além da dualidade entre identidade pessoal e social. Reforçando essa ideia, Ciampa (2005) propõe que a identidade seja concebida como a mesmidade de pensar e ser, ou seja, quando o indivíduo busca ser ele mesmo, não como forma de buscar sua essência, mas de ser ele mesmo como um ser que é determinado a partir da identidade. Ciampa (2005), aludindo ao filósofo Heidegger, defende que o ser faz parte da identidade, e não o contrário: a identidade faria parte do ser.

Para Ciampa (2005), é crucial a eliminação da perspectiva essencialista da identidade, pois, nessa visão, a identidade aparece como um objeto misterioso e fantasmagórico, como um fetiche, similar à ideia marxista de mercadoria. A identidade é vista como estática, concebida isoladamente, na condição de "ser-para-si". Cria-se, dessa forma, o que Ciampa (2005, p. 146) denomina de "identidade-mito, o mundo da mesmice (da não-mesmidade) e da má infinidade (a não superação das contradições)". A ideia de identidade essencialista faz com que as pessoas se deparem frequentemente com a necessidade de protelar transformações, evitar a evidência de mudanças, para que, de alguma forma, continuem sendo o que chegaram a ser em um dado momento de suas vidas. As pessoas se trasformam, sem perceber, em uma "réplica, numa cópia daquilo que já não estão sendo, do que foram" (CIAMPA, 2005, p. 165). 
Segundo Arendt (2004), o homem é o único ser capaz de exprimir a diferença que ele possui dos demais, de se distinguir das outras pessoas. Só ele é capaz de comunicar a si próprio. A distinção dos demais vem à tona no momento em que se inicia a atividade humana no mundo. Agindo, os seres humanos se manifestam uns aos outros e, somente assim, assumem a condição de seres humanos, se tornam algo além de meros objetos físicos e vão além da mera existência corpórea. Nesse sentido, a revelação de alguém estaria implícita tanto em suas palavras quanto em seus atos.

Mesmo quando as palavras e os atos possuem conteúdo exclusivamente objetivo, voltado para questões do mundo das coisas, eles ainda conservam a capacidade de revelar o agente por trás. Notadamente, na grande maioria dos casos, palavras e atos se referem à mediação entre os homems e seus interesses específicos, objetivos e mundanos. Nesse sentido, revela-se o agente que fala e age no momento em que este estabelece algum tipo de relação com a realidade mundana e objetiva (ARENDT, 2004).

A tendência em se buscar características essenciais capazes de identificar o indivíduo, conferindo-lhe uma identidade única, seria refletida e reforçada pela linguagem cotidiana. Entretanto, trata-se de tarefa frustrante a tentativa de se expressar verbalmente a identidade revelada de quem fala e age. Ciampa (2005) nota a dificuldade em se referir a alguém somente por meio de verbos, por exemplo, sem usar substantivos e adjetivos. Ao substantivar o indivíduo no discurso, cria-se a ilusão de uma substância de que ele seria dotado e que se expressaria através dele. No momento em que se tenta definir quem alguém é, constrói-se um personagem com as características que a pessoa partilha com outras que lhe são semelhantes. Não se diz quem a pessoa é, mas o que ela é (ARENDT, 2004).

Nesse processo, perde-se de vista o que cada indivíduo possui de singular e específico. Ao se solidificar em palavras a essência viva de alguém, essência esta que é fluida, corre-se o risco de se tratar identidades como coisas cuja natureza podemos dispor e nomear (ARENDT, 2004). Portanto, o indivíduo, enquanto ser ativo, "coisifica-se sob a forma de uma personagem que subsiste independentemente da atividade que a engendrou e que deveria sustentar" (CIAMPA, 2005, p. 133). Esse processo linguístico acaba reforçando a ideia de uma identidade inata e imutável, independente da atividade do indivíduo no mundo.

Para Ciampa (2005), não se pode retirar o caráter de historicidade da identidade, pois, dessa forma, ela se aproxima da noção de um mito que prescreve as condutas corretas e re-produz o mundo social. As identidades pressupostas, tidas como algo dado, contribuem para a manutenção do sistema da forma como ele está, sendo cada um responsável por manter sua identidade, por ser coerente com as expectativas alheias. Nesse sentido, é crucial conceber a revelação da identidade como um processo que emerge mais tarde como a história singular de uma vida. A construção da identidade teria seu fim somente com a morte, quando o indivíduo para de se manifestar enquanto sujeito (ARENDT, 2004).

Cabe lembrar que a construção histórica de cada identidade incide em uma teia de relações já existentes e nela imprime suas consequências imediatas. A emergência de uma história de vida singular se dá necessariamente em interação mútua com as histórias de vida de todos aqueles com quem se entra em contato. Graças à interação nesse meio é que se produz história, intencionalmente ou não (ARENDT, 2004). A partir disso, estabelece-se uma rede de reflexões, em que as identidades se refletem e se reforçam, por meio de representações (CIAMPA, 2005).

Esse jogo de reflexões múltiplas que estrutura as relações sociais é mantido pela atividade dos indivíduos, de tal forma que é lícito dizer-se que as identidades, no seu conjunto, refletem a estrutura social, ao mesmo tempo que reagem sobre ela, conservando-a (ou transformando-a) (CIAMPA, 2005, p. 171).

Destaca-se, portanto, a inevitabilidade com que os homens se revelam como sujeitos, como pessoas distintas e singulares, mesmo quando interagem de forma a alcançar objetivos materiais e mundanos e quando corroboram a estrutura das relações sociais. A atividade no mundo pressupõe posicionamento, revelação e, 
assim, humanidade. "Eliminar essa revelação - se isto de fato fosse possível - significaria transformar os homens em algo que eles não são; por outro lado, negar que ela é real e tem consequências próprias seria simplesmente irrealista" (ARENDT, 2004, p. 196).

Portanto, concordando-se com Ciampa (2005) e Arendt (2004), estudar a identidade como representação, é entendê-la como produto, mas não se pode deixar de lado o entendimento da identidade enquanto produção, pois o indivíduo não é exatamente algo, mas sim o que ele faz. Sendo o fazer sempre atividade no mundo, em relação com os outros, o pesquisar sobre identidade se desloca de uma questão meramente descritiva para a questão "de compreensão, de entendimento", sendo necessário "captar os significados implícitos, considerar o jogo das aparências. A preocupação é com o que se mostra velado" (CIAMPA, 2005, p. 139).

\section{Definições de práticas}

Tendo em vista os possíveis equívocos de se estudar a identidade fora da esfera cotidiana, fora das práticas, como algo descolado daquilo que o indivíduo pratica no seu dia-a-dia, considera-se de grande importância a análise da ação, da atividade ou da vida prática dos sujeitos. Nesse sentido, recorreu-se a basicamente três sistemas de conceituações, para clarificação dos termos: as definições de Arendt (2004) sobre os aspectos da vita activa; as definições de "estratégias" e "táticas" de Certeau (1994); e a definição de prática discursiva cunhada por autores como Foucault (2006, 2007) e Fairclough (2003), entre outros.

Para Arendt (2004) a vita activa humana se separa em três tipos de atividade: o labor, o trabalho e a ação. O labor estaria relacionado com as necessidades vitais do corpo humano, seu metabolismo, com os processos biológicos que ocorrem espontaneamente durante o crescimento e declínio do ser humano. O labor seria a atividade humana voltada à própria vida. Já, o trabalho, por sua vez, se relacionaria às atividades de produção de um mundo artificial de coisas. Os produtos do trabalho humano seriam nitidamente diferentes de qualquer ambiente natural e seriam destinados à sobreviver e transcender vidas individuais. $\mathrm{O}$ mundo artificial, portanto, seria construído pelo homem, mas perduraria além da existência de uma pessoa, ou seja, seria um produto independente da existência humana. $O$ trabalho seria a atividade humana voltada à mundanidade, à produção de um mundo artificial no qual os indivíduos vivem.

Por fim, a ação seria a atividade humana ligada à interação entre homens, sem a mediação das coisas ou da matéria. É por meio da ação que os indivíduos se revelam distintos uns dos outros e, ao mesmo tempo, se igualam enquanto seres humanos. A ação seria a atividade humana destinada à pluralidade. $\mathrm{O}$ ser que age nunca age exatamente igual a qualquer pessoa que tenha existido, exista ou venha a existir. Somente por causa de sua capacidade de ação que o homem pode ter vida política.

Labor, trabalho e ação são três componentes da vita activa imprescindíveis à manutenção da condição humana. Os três tipos de atividade encontram-se interligados e interdependentes.

O labor assegura não apenas a sobrevivência do indivíduo, mas a vida da espécie. O trabalho e seu produto, o artefato humano, emprestam certa permanência e durabilidade à futilidade da vida mortal e ao caráter efêmero do tempo humano. A ação, na medida em que se empenha em fundar e preservar corpos políticos, cria a condição para a lembrança, ou seja, para a história (ARENDT, 2004, p. 16-17).

Os três tipos de atividade humana são apontados por Arendt (2004) como condicionados pelo fato de os homens viverem juntos. Contudo, a ação é a única categoria que não poderia sequer ser imaginada fora da vida em sociedade. O homem poderia laborar e trabalhar de forma isolada na natureza. Ele perderia sua condição humana e assumiria uma nova forma de existência, mas seria uma situação hipotética verossímil. Contudo, seria impossível conceber um ser humano isolado capaz de agir. A ação é prerrogativa exclusiva ao 
homem, em constante presença de outros. É a capacidade de ação que impede que o comportamento dos homens seja apenas repetições intermináveis e previsíveis, segundo leis gerais, uma mesma natureza e essência.

Portanto, para Arendt (2004), seria por meio da ação que os indivíduos manifestam suas identidades, suas essências, inigualáveis a qualquer outro ser existente. É por meio da ação que os homens se organizam politicamente, em meio ao ambiente criado pelas coisas fabricadas no trabalho e pelas atividades de sobrevivência diária do labor. A ação confere o sentido histórico e o caráter humano ao mundo e às atividades de labor e trabalho. A partir dessa noção, é possível entender que, por meio da ação, estabelecemse as relações de poder típicas de uma sociedade. Relações estas que organizam as formas de atividade humana, determinam os indivíduos e os espaços de labor, de trabalho e de ação. Contudo, ao se adentrar na esfera cotidiana, tais divisões parecem se confundir em um contexto múltiplo de práticas.

Para Certeau (1994), o cotidiano é construído por meio de bricolagens dos vários indivíduos que compartilham de um mesmo espaço. Os dominados seriam capazes de se apropriar da esfera simbólica constituída pelos dominantes e transformá-la, ressignificá-la, de acordo com suas próprias necessidades e possibilidades. Dessa forma, constituem-se movimentos de resistência por parte dos dominados, mas sem que isso se transforme necessariamente em ameaça ao poder simbólico dos dominantes do território. A partir das ideias de Certeau (1994), portanto, é possível conceber como a identidade se constrói cotidianamente no processo de bricolagens. Para construir suas identidades, os indivíduos se apropriam da esfera simbólica do espaço onde se encontram, agindo sobre ela e se auto-definindo enquanto sujeitos.

Nesse sentido, Certeau (1994) desenvolve os conceitos de estratégia e de tática para compreender a natureza da multiplicidade de atividades que constroem o cotidiano. As estratégias são cálculos de relações de força que se tornam possíveis a partir do momento em que um sujeito de querer e poder é isolável das exterioridades. Ou seja, o modelo estratégico presume a existência de um lugar circunscrito, no qual existem relações de dominação e regras prescritivas de conduta. Já a tática seria "um cálculo que não pode contar com um próprio, nem portanto com uma fronteira que distingue o outro com totalidade visível" (CERTEAU, 1994, p. 46).

Nesse sentido, as táticas são contextuais e oportunistas, frutos da inteligência cotidiana. São práticas que se aproveitam de uma certa situação para gerar resultados imediatos. No espaço do outro, as táticas se aproveitam do tempo, para captar possibilidades de ganho. Enquanto as estratégias se relacionam com o poder exercido em um lugar próprio ou em uma instituição, as táticas se relacionam com a astúcia popular. A estratégia é destinada ao acúmulo futuro, à prescrição e ao controle. Já a tática é contextual e efêmera. "O que ela ganha, não o guarda" (CERTEAU, 1994, p. 47).

A partir da definição dos conceitos de estratégia e tática, Certeau (1994) estabelece as relações de poder existentes dentro de determinados territórios. Para o autor, os dominados não são necessariamente passivos ou dóceis. No seu cotidiano, eles jogam com os mecanismos dominadores, usando inúmeras e infinitesimais metamorfoses da lei, segundo seus interesses próprios e suas próprias regras. Portanto, as táticas seriam intrinsecamente formas de resistência, seriam "mil maneiras de jogar/desfazer o jogo do outro, ou seja, o espaço instituído por outros, caracterizam a atividade, sutil, tenaz, resistente, de grupos que, por não ter um próprio, devem desembaraçar-se em uma rede de forças e de representações estabelecidas" (CERTEAU, 1994, p. 79).

Partindo-se da visão de Certeau (1994), entende-se que as táticas servem a determinado poder em uma certa situação, sendo esse poder estratégico ou resistente. Em ambientes organizacionais, onde há claramente um grupo dominante e um estratégia definida, as táticas seriam as "artes de fazer" dos indivíduos que manipulam as regras vigentes em benefício próprio. Tais táticas, entretanto, poderiam ou não ser subversivas e prejudiciais à consecução da estratégia. Ao visar o benefício próprio, o indivíduo pode entrar em choque com os objetivos da organização ou pode fazer uso de tais objetivos para obter vantagens. Isto dependeria, basicamente, da forma como o indivíduo percebe o poder da organização e como ele se insere nesse sistema 
de poder. Dependeria de como ele se vê nesse sistema, como colaborador ou como explorado, e de como ele vislumbra expectativas no interior da organização. Em outras palavras, dependeria se o indivíduo vislumbra a mobilidade social ou a mudança estrutural (TAJFEL, 1981).

Para se compreender como são formadas as estratégias e táticas em uma organização, deve-se penetrar na esfera cotidiana, conhecendo seus aspectos simbólicos, sua história, seu senso comum e as identidades que a permeiam. Tais fatores são importantes para se compreender porque determinadas práticas estratégicas são selecionadas no espaço organizacional. Pensar e agir estratégica ou taticamente envolveria a manifestação de quem o indivíduo é (identidade individual) na organização, a qual(is) grupo(s) ele pertence (identidade coletiva) e o que a organização é em comparação a outras (identidade da organização). Ademais, os movimentos táticos e estratégicos tomados diariamente pelos atores organizacionais constroem e reconstroem as identidades, sendo por fim a própria expressão das mesmas.

Nesse processo, destaca-se o papel crucial das práticas, principalmente, das práticas discursivas na construção da identidade. "Os discursos e os sistemas de representação constroem os lugares a partir dos quais os indivíduos podem se posicionar e a partir dos quais podem falar" (WOODWARD, 2000, p.17). A revelação sobre quem alguém é se dá tanto por seus atos, quanto por suas palavras, contudo, sem o discurso, a ação perde seu caráter revelador da identidade, perde seu sujeito. Sem o discurso, a ação perde seu ator ou agente do ato e deixa, portanto, de ser ação propriamente dita (ARENDT, 2004).

Foucault (2007), ao apresentar seu método arqueológico de estudo dos discursos, busca primeiramente diferenciá-lo da disciplina "História das Ideias". Para o autor, o discurso tem um papel muito maior na sociedade do que simples reflexo das ideias, como algo ulterior às modificações no mundo material e na esfera ideal. Os discursos devem ser analisados ao longo da história como práticas discursivas, como agentes transformadores, reificadores e instauradores de verdades, poderes, convenções, instituições. Foucault (2006) propõe estudar a história dos discursos, ou a arqueologia do saber, que seria analisar os dispositivos de poder e de saber, que instauram verdades e silêncios. A partir da identificação de tais dispositivos, seria necessário investigar as condições em que os discursos surgem e funcionam, como eles se formam, quais as consequências de seu uso e quais as estratégias de poder imbuídas.

Uma questão importante das práticas discursivas é a formação dos objetos discursivos. Todo discurso constrói seus próprios objetos, nos quais se apóia e se desenvolve. Foucault (2007) descreve os mecanismos para evidenciar o surgimento desses objetos. Primeiramente, é necessário analisar as superfícies primeiras de sua emergência, ou seja, mostrar em que contextos surgiram, quais os campos de diferenciação primeira, as descontinuidades e os limiares. Nessas superfícies, os discursos encontram a possibilidade de limitar seus domínios, de definir seus objetos e dar-lhes status. Em segundo lugar, é preciso identificar as instâncias que operam na delimitação dos objetos. Finalmente, devem-se analisar as grades de especificação, com as quais se separa, agrupa, associa, classifica e deriva uns e outros objetos.

Os objetos não preexistem ao discurso, surgem a partir do feixe de relações que se instaura em um dado momento. Em cada época, é possível falar de certos objetos, sendo difícil falar subitamente de algo novo, de um objeto jamais dito. As relações que determinam um objeto se encontram fora dele e são estabelecidas entre instituições, processos econômicos e sociais, formas de comportamentos, sistemas de normas, técnicas e classificações. Dentre tais relações, há as relações discursivas, que não são internas ao discurso, mas também não são totalmente externas a ele, a ponto de forçar o surgimento de enunciados. As relações discursivas:

[...] estão, de alguma maneira, no limite do discurso: oferecem-lhe objetos de que ele pode falar, ou antes (...), determinam o feixe de relações que o discurso deve efetuar para poder falar de tais ou tais objetos, para poder abordá-los, nomeá-los, analisá-los, classificá-los e explicá-los etc. (FOUCAULT, 2007, p. 51). 
Essas relações caracterizam o próprio discurso enquanto prática. A partir delas, o discurso organiza não apenas objetos, mas também conceitos, agrupamentos de objetos, temas, teorias e a própria identidade do enunciador. Entretanto, "todos esses grupamentos de enunciados que devemos descrever não são a expressão de uma visão do mundo que teria sido cunhada sob a forma de palavras, nem a tradução hipócrita de um interesse abrigado sob o pretexto de uma teoria" (FOUCAULT, 2007, p. 76). Para Foucault (2007), a ideologia está menos presente nas escolhas do conteúdo discursivo do que na própria prática discursiva, na apropriação dos discursos em prol de interesses ideológicos.

Segundo Fairclough (2003), em se tratando de significação e comunicação, a linguagem seria um elemento presente em todos os níveis de interação social: estrutura, prática e evento. Como estrutura, entende-se a língua, que define certas possibilidades de combinar elementos linguísticos e as regras gramaticais. Como prática social, apontam-se as ordens de discurso, que seriam redes de práticas sociais em seus aspectos linguísticos. Já como eventos sociais, apontam-se os textos. Ressalta-se que, conforme se desloca do nível mais abstrato para o mais concreto, a linguagem passa a ser cada vez mais influenciada por outras condições sociais e não apenas pelas restrições linguísticas.

As ordens de discurso podem ocorrer de três formas. Como gêneros, que são formas de agir e interagir discursivamente, como parte de uma ação. Como representações, que são a forma como o discurso representa o mundo material, outras práticas sociais ou se autorrepresenta. A representação se refere ao conteúdo do discurso, segundo diferentes perspectivas ou posições. Por último, como estilos, que são formas de ser e que constituem identidades pessoais ou sociais (FAIRCLOUGH, 2003).

De forma análoga, no nível textual, Fairclough (2003) também distingue três funções dos textos, ou seja, suas relações com o evento social em questão, com o mundo material e social mais amplo e com os indivíduos envolvidos no evento. Nesse sentido, o texto se configura como uma ação, pois estabelece uma relação social. Configura-se também como uma forma de representação, pois apresenta em seu conteúdo maneiras de ver o mundo. Por fim, pode ser ainda entendido como uma forma de identificação, ao implicar em compromissos, julgamentos e posicionamentos do enunciador. Essas três funções podem ser observadas simultaneamente em um mesmo texto ou podem ser observadas em diferentes partes do mesmo texto.

Reside, nos atos de fala, a natureza dialógica da construção discursiva, de acordo com a teoria bakhtiniana. Isto porque tais atos são constituídos por enunciados cujos sentidos são construídos socialmente, em constante diálogo com duas ou mais vozes. As vozes compreendem diálogos, negociações, discursos existentes previamente ao enunciado e com os quais ele se constrói. Os atos de fala podem ser compreendidos em sentido amplo e, nos dias atuais, rádio, televisão e sites da Internet podem também ser considerados como tais. Entretanto, o caráter polissêmico da linguagem não impede a tendência à hegemonia de determinados sentidos e discursos, e nem as diferenças de poder entre as práticas discursivas em provocar mudanças (BAKHTIN, 1992; SPINK e MEDRADO, 1999).

Fairclough (2003) ainda coloca que as três categorias por ele apontadas podem ter seu potencial interpretativo enriquecido se relacionadas a outras teorias sociais. Por exemplo, com relação à teoria de Foucault, a representação discursiva vai além do conhecimento para se tornar o controle sobre as coisas. A ação não se refere apenas às relações sociais, mas também à ação sobre outros e ao exercício do poder. $\mathrm{E}$ a identificação, por sua vez, tem a ver com o enunciador, refletindo sua ética e moral.

Apesar de as três categorias terem sido claramente distinguidas com propósitos analíticos, elas se encontram interrelacionadas dialeticamente. Formas particulares de representação (discursos) são acionadas por formas particulares de agir e de se relacionar (gêneros), que são inculcadas por formas particulares de identidade (estilos). Ao se tratar especificamente de identidades, portanto, os estilos adquirem importância, pois são os aspectos discursivos das formas de ser, de se revelar enquanto enunciador. Quem o indivíduo é está relacionado à forma como ele fala, escreve e aparenta ser. Os estilos são observados em vários aspectos linguísticos. Primeiro, em termos fonológicos, destacam-se a pronúncia, entonação, estresse, ritmo. Segundo, em termos de vocabulário e metáforas, pode-se destacar o uso de advérbios de intensidade e de palavras de 
impacto. Os estilos, além disso, envolvem a interrelação entre linguagem, linguagem corporal e estilos de vestir, de usar o cabelo, entre outros (FAIRCLOUGH, 2003).

Por meio da análise textual, é possível compreender a identificação do indivíduo em termos de modalidade e avaliação. Esses dois elementos se relacionam a que o enunciador se compromete em seu texto, sobre o que é verdadeiro e necessário (modalidade) e sobre o que é desejável ou indesejável, bom ou ruim (avaliação). A modalidade seria o julgamento do enunciador sobre probabilidades e obrigações envolvidas no que ele está falando. É o relacionamento entre o enunciador e suas representações (FAIRCLOUGH, 2003).

É importante avaliar a modalidade em um texto para desvendar a identidade do enunciador pois os elementos com que o indivíduo se compromete no discurso são partes significantes do que ele é. Sendo a identidade um atributo relacional, o que o indivíduo é se baseia na forma como ele se relaciona com o mundo e com outras pessoas. Ademais, as escolhas de modalidade são limitadas pelas relações sociais. A avaliação, por sua vez, pode ser observada em afirmações avaliativas, imperativas, afetivas ou quando o enunciador se refere explícita ou implicitamente a um sistema de valores. De qualquer forma, qualquer tipo de avaliação demonstra o compromisso do enunciador com valores, o que sinaliza vínculos de identificação (FAIRCLOUGH, 2003).

Existem outros elementos discursivos relacionados ao estilo e às identidades. Um deles é a tensão entre os sentidos de unicidade, ou seja, demonstrar-se como um indivíduo único e dotado de personalidade, e os sentidos de sociabilidade, ou seja, ser um indivíduo comum, que se encaixa em determinado papel social. Fairclough (2003) demonstra que, em um mesmo texto, o enunciador pode construir ambos os sentidos sobre si. Outra questão importante é a análise estética da identidade, que perpassa pela semiotização de aspectos visuais da enunciação, assim como a análise retórica das estruturas gramaticais empregadas.

$\mathrm{Na}$ tentativa de uma visão integradora dos sistemas de conceituações expostos neste subitem, entende-se que a identidade do indivíduo encontra-se expressa basicamente quando este interage direta ou indiretamente com o outro. Nesse sentido, somente a partir da ação é que o indíviduo realmente se posiciona e é capaz de manifestar quem ele é em sua essência (ARENDT, 2004). Em um contexto de relações de poder, tais movimentos interativos assumem um posicionamento estratégico ou tático. Para os dominados, isso significa assumir uma posição de resignação ou de resistência (CERTEAU, 1994). Partindo-se do pressuposto de que a ação desprovida da esfera discursiva não é ação propriamente dita, pois não revela seu ator e não permite sua manifestação interativa (ARENDT, 2004), é possível sustentar a ideia de que, para a análise da identidade, toda prática passa por sua dimensão discursiva - mesmo as práticas não-verbais seriam transpostas ao nível discursivo, ou semiotizadas, para que o pesquisador possa desvendar seu significado e a identidade de seu ator (FAIRCLOUGH, 2003). Portanto, propõe-se, neste ensaio, a seguinte articulação teórica para a compreensão da identidade:

Figura 1
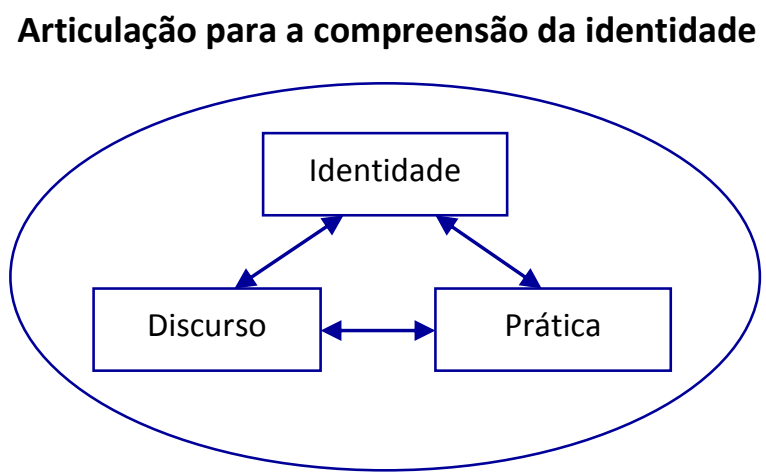

Fonte: Elaborado pelos autores. 
Nesse sentido, o estudo da identidade perpassaria necessariamente a análise das práticas ou das ações dos indivíduos e a apreensão destas se dá somente por meio da semiotização, ou seja, da interpretação dos sentidos de quem agiu. Mesmo que a ação em análise não seja verbal, leva-se também em consideração o discurso não-verbal do indivíduo. Trata-se, dessa forma, de uma tríade de dimensões inseparáveis. É necessário reconhecer, no entanto, que o processo de interpretação dessas dimensões será sempre falho, pois perpassa inevitavelmente pela interpretação de um agente exterior, neste caso, do pesquisador. O pesquisador nunca será capaz de desvendar inteiramente a construção de sentidos do indivíduo no momento em que ele age e, assim, também não é capaz de apreender integralmente qual seria sua identidade. No processo de análise discursiva/semiótica, o pesquisador irá apreender parcialmente os sentidos e a interpretação dos mesmos sofrerá interferências de sua própria subjetividade.

Tendo consciência de tais limitações, seria estimável que o pesquisador busque aproximar-se o máximo possível da realidade dos sujeitos pesquisados, por exemplo, por meio de observações participantes e entrevistas em profundidade. Ademais, na análise da identidade no contexto organizacional, é importante considerar o agir no espaço (físico e simbólico), focando a relação da identidade individual com a construção da identidade coletiva e interpretando a ação segundo o tipo de racionalidade que a permeia. A questão da racionalidade foi entendida como primordial para que a análise da identidade estivesse compatível com os posicionamentos ontológicos e epistemológicos relacionados à concepção da identidade autônoma (CARRIERI, PAULA e DAVEL, 2008). Ao se distinguir diferentes tipos de racionalidade, admite-se que o agir humano não se pauta somente pela razão cartesiana. Admitem-se assim, a pluralidade humana e a capacidade de refletir e agir a partir de motivações que transcendem a existência mundana. Portanto, ao esquema apresentado anteriormente é necessário ainda adicionar a dimensão das racionalidades.

\section{Racionalidades}

Conforme já exposto, na perspectiva assumida neste ensaio, admitem-se como verdadeiros os pressupostos da filosofia negativa, a qual postula que a verdade está no pensamento utópico do homem, a partir de momentos em que este é capaz de transcender a realidade imediata para refletir sobre possibilidades de um mundo melhor no futuro. A partir de tal pensamento, os homens poderiam agir, basicamente, segundo dois conjuntos de critérios, aqueles relacionados à existência mundana e aqueles relacionados à transcendência das condições materiais.

Ao se tratar do tema da racionalidade, Max Weber é apontado como figura relevante (RAMOS, 1981; MANNHEIM, 1986). Ele teria sido pioneiro ao diferenciar quatro tipos de racionalidade:

A ação social, como toda ação, pode ser determinada: 1) de modo racional referente a fins: por expectativas quanto ao comportamento de objetos do mundo exterior e de outras pessoas, utilizando essas expectativas como 'condições' ou 'meios' para alcançar fins próprios, ponderados e perseguidos racionalmente, como sucesso; 2) de modo racional referente a valores: pela crença consciente no valor - ético, estético, religioso ou qualquer que seja sua interpretação - absoluto e inerente a determinado comportamento como tal, independentemente do resultado; 3) de modo afetivo, especialmente emocional: por afetos ou estados emocionais atuais; 4) de modo tradicional: por costume arraigado (WEBER, 2004, p. 15).

Mannheim (1986), a partir das ideias de Weber, discorre sobre a racionalidade funcional e a substancial. A primeira estaria baseada na orientação da conduta como sendo apenas meio para se atingir um fim. Cada ato assume papel funcional na consecução do objetivo final, sendo necessária a coordenação de uma série de atos da forma mais eficiente possível para se atingir a meta esperada. Cada série de atos tem suas consequências calculadas e organizadas funcionalmente em relação ao objetivo. A racionalidade funcional 
seria verificável, por exemplo, em estruturas organizadas segundo planos de uma cúpula estratégica ou em sociedades tradicionalistas em que as ações individuais adquirem sentido somente em função do sistema como um todo (MANNHEIM, 1986).

A racionalidade substancial, por sua vez, opera na orientação da conduta segundo imperativos éticos ou estéticos, valores transcendentes à condição natural, funcional e socialmente determinada. Ramos (1981) afirma que o agir substancialmente racional fundamenta a transformação do homem em ator político, capaz de uma conduta autêntica e responsável. Por meio da racionalidade substancial, seria possível o "ato de pensamento que revele percepção inteligente das interrelações dos acontecimentos de uma determinada situação" (MANNHEIM, 1986, p. 63).

É possível aplicar o conceito de funcional e substancial à ideia da moralidade. Padrões morais do tipo funcional levariam a condutas pautadas apenas em prol da suavização do funcionamento da sociedade. Por outro lado, uma moralidade do tipo substancial estaria arraigada em valores transcendentes, baseados na fé, na ética, na estética ou em outros tipos de sentimento, considerados autênticos pelo sujeito mas que podem parecer irracionais sob a ótica funcional. Nesse sentido, para Mannheim (1986, p. 77), existiriam duas formas de proibições e tabus, observáveis durante toda a História humana: “(...) as que garantem o funcionamento da sociedade em questão e as que expressam atitudes emocionais particulares, tradições, ou mesmo idiossincrasias de um grupo".

Mannheim (1986) chama a atençao para a tendência moderna de se neutralizar cada vez mais a moralidade substancial, principalmente, no espaço público. As decisões na esfera pública pautam-se cada vez mais em padrões universais de tolerância, que possuem significação meramente funcional. Nesse sentido, é entendido como bom e correto o que facilita o funcionamento das relações sociais. A predominância de padrões morais funcionais impediria as qualificações éticas da vida humana. O ordenamento da vida passa a ser concebido como algo extrínseco. Cada indivíduo aceita regular e limitar suas próprias paixões, de modo a não ameaçar seus interesses práticos e garantir seus ganhos. Nesse sentido, valores humanos se tornam equivalentes a valores econômicos. A noção de moralidade se reduziria a acordos explícitos ou tácitos baseados em cálculos utilitários das consequências (MANNHEIM, 1986; RAMOS, 1981).

Tendo em vista que tal processo levaria à própria desumanização das relações sociais, seria necessário proteger a vida humana contra a expansão da racionalidade funcional. Tal processo seria agravado pela industrialização. Mannheim (1986, p. 65) salienta que um alto grau de desenvolvimento técnico e econômico não significaria necessariamente alto grau de desenvolvimento ético:

[...] quanto mais industrializada uma sociedade, mais avançada sua divisão do trabalho e sua organização, maior será o número de esferas de atividade humana funcionalmente racionais e portanto também previsíveis antecipadamente. Enquanto o indivíduo nas sociedades antigas apenas ocasionalmente e em esferas limitadas, agia de uma maneira funcionalmente racional, na sociedade contemporânea ele é obrigado a agir dessa forma em um número de esferas de vida cada vez maior.

Partindo das distinções conceituais de Weber (2004) e das reflexões de Mannheim (1986), Ramos (1981) sustenta que a racionalidade substancial é imprescindível à capacidade humana de transcendência e a sua qualidade de criatura racional. Atos racionalmente substanciais representam a preocupação do homem em resguardar sua liberdade. Somente assim, o indivíduo liberta sua ação de sistemas positivos de integração a outros atos, agindo inteligentemente.

Ramos (1981) propõe que a racionalidade substantiva se constitua como uma categoria essencial para a teorização sobre a vida humana associada. Nesse sentido, ele compara que, enquanto na teoria substantiva, os conceitos seriam derivados do e no processo de realidade, em uma teoria formal, os conceitos seriam apenas instrumentos convencionais de linguagem, que descrevem procedimentos operacionais. Ao negligenciar a racionalidade substancial e ao silenciar sobre seus pressupostos filosóficos, a ciência moderna se torna a 
metodologia de uma realidade histórica predeterminada, a qual ela reforça. O caráter instrumentalista interno do método científico revela uma relação estreita entre o pensamento científico e sua aplicação. Relação esta que segue a lógica e a racionalidade de dominação. A ciência moderna é uma tecnologia apriorística, que funciona como controle social (MARCUSE, 1973).

A conjugação da racionalidade instrumental com a ciência moderna dá origem à chamada racionalidade tecnológica. $\mathrm{O}$ aparato técnico de produção e distribuição funcionaria como um sistema que determina $a$ priori seu produto e as operações de sua manutenção e ampliação. $\mathrm{O}$ aparato produtivo se torna totalitário, pois determina não só as oscilações, habilidades e atitudes socialmente necessárias, como também as necessidades e aspirações individuais. "No ambiente tecnológico, a cultura, a política e a economia se fundem num sistema onipresente que engolfa ou rejeita todas as alternativas. $\mathrm{O}$ potencial de produtividade $\mathrm{e}$ crescimento desse sistema estabiliza a dominação. A racionalidade tecnológica ter-se-á tornado racionalidade política" (MARCUSE, 1973, p. 19).

A racionalidade tecnológica opera na escravização progressiva do homem pelo aparato produtor, reduzindo sua vida à luta pela existência. Contudo, tal racionalidade se torna ainda mais suspeita tendo em vista que a existência pela qual se luta em tais condições deixa de ser uma existência humana, pois prescinde de liberdade, vida política e necessidade de transcendência. Guiado pela razão instrumental tecnológica, o homem aceita sua submissão ao aparato técnico para ampliar as comodidades de sua existência e aumentar sua produtividade no trabalho. Cria-se, portanto, uma sociedade racionalmente totalitária. "A força libertadora da tecnologia - a instrumentalização das coisas - se torna o grilhão da libertação; a instrumentalização do homem" (MARCUSE, 1973, p. 155).

Diante da constatação do totalitarismo racional vigente na sociedade moderna, Marcuse (1973) propõe a restauração da racionalidade transcendente, para que as realizações produtivas da civilização fossem apropriadas em prol da pacificação da existência, conferindo maior possibilidade de livre desenvolvimento das necessidades e faculdades humanas. $\mathrm{O}$ autor coloca que tal racionalidade envolve inevitavelmente julgamentos de valor e premissas tomadas como verdades a priori.

Citando Whitehead, Marcuse (1973) afirma que a função da Razão é promover a arte da vida, ou seja, é buscar viver cada vez melhor. Nesse sentido, a arte, como atividade transcendental, significa a negação das condições reais, em busca de uma verdade superior. Contudo, na sociedade moderna, a Razão tem sido colocada como o oposto da arte, concedendo à arte o privilégio de ser irracional, não sujeita à Razão científica, tecnológica e instrumental. Sendo a arte irracional, a Razão da ciência assumiu para si o compromisso em buscar uma vida melhor. Contudo, a racionalidade científica fracassou em tal empreitada, pois conservou o compromisso com a não-liberdade no qual ela nasceu, com a negação de uma verdade superior.

Uma racionalidade pós-tecnológica submeteria a técnica à arte da vida, à libertação da brutalidade e insuficiência da Natureza, à redução da miséria, da violência e da crueldade. Nesse sentido, a função da Razão converge com a função da arte. A racionalidade específica da arte está fundada nas ideias do artista, como causa final. A partir disso, ela parte para a construção de certas coisas. A arte necessariamente cria outro universo de pensamento e prática, contra o existente e, ao mesmo tempo, dentro dele (MARCUSE, 1973).

A capacidade inerente à arte de projetar a existência e definir possibilidades, ao invés de ser capturada pelo sistema como simples forma de embelezamento da realidade, deveria se tornar uma técnica para destruir os negócios e a miséria. A arte transforma o objeto natural, pois interfere em seus significados instrumentais e contingenciais por meio de um aparato que é livre e racional. Transformando a natureza, que é opressiva, a arte se torna uma forma de libertação. Nesse sentido, torna-se manifestação da racionalidade substantiva, do verdadeiramente racional ou do irracional segundo o ponto de vista instrumental. 
Entende-se, nessa perspectiva, que a ação humana pode ser pautada a partir de critérios racionais de diferentes naturezas. Tomar-se-á como básicos os dois tipos de racionalidade distinguidos por Mannheim (1986) e trabalhados por Ramos (1981): a racionalidade instrumental e a racionalidade substancial. Na contemporaneidade, a racionalidade instrumental encontra-se conjugada aos valores da ciência e do progresso tecnológico, o que leva à expansão da instrumentalização do ser humano a quase todas as esferas de sua vida. Contudo, acredita-se ainda haver espaços para a racionalidade substantiva, relacionada à busca pela liberdade, pela vida autêntica, pela conduta ética e pela vida política. Um exemplo seriam as atividades artísticas (MARCUSE, 1973; RAMOS, 1981).

Tais espaços estariam relacionados aos momentos de transcendência das condições existenciais dadas. Seria nesses momentos livres que o indivíduo empreenderia práticas que revelam sua verdadeira identidade, sua essência. Nos demais momentos, empreendendo ações instrumentais, o indivíduo se revela apenas como instrumento de um aparato técnico que se impõe sobre ele. Nesse sentido, a partir da ideia de que as racionalidades orientam as ações, é possível se falar de identidades substantivas e identidades instrumentais (LIMA, HOPFER e LIMA-SOUZA, 2004). Acrescentam-se tais dimensões à esquematização apresentada no subitem anterior:

Figura 2

\section{Dimensões da identidade segundo as racionalidades}

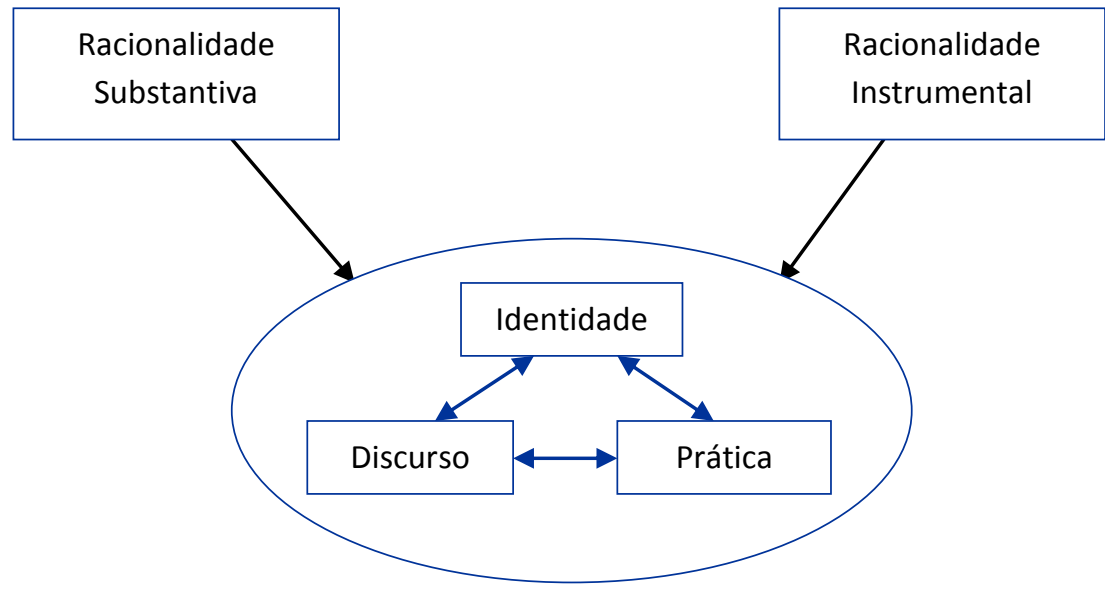

Fonte: Elaborado pelos autores.

A identidade substantiva estaria relacionada à autorrealização e ao autoconhecimento do sujeito, ao passo que a identidade instrumental estaria relacionada à conveniência, à aceitação do outro, aos papéis sociais. Lima, Hopfer e Lima-Souza (2004) realizaram um estudo levando em conta essas duas dimensões da identidade, chamando a atenção para a crescente centralização da identidade instrumental, notadamente, devido à predominância do trabalho no processo de construção da identidade e ao processo de reestruturação tecnológica. Contudo, observou-se a necessidade de se explorar melhor os processos de construção da identidade, a partir das racionalidades.

\section{Identidade instrumental}

A realidade social é construída a partir da participação e interação dos indivíduos. Entretanto, segundo Ramos (1981, p. 128), o caráter dessa participação difere de um indivíduo para outro: "pode ser um caráter ativo, caso em que o indivíduo é um existente real (isto é, um ego, uma pessoa) ou pode ser meramente 
reativo. Neste último caso, o indivíduo perde o caráter de ser real e transforma-se num simples sistema de processamento da informação (...)”.

Em muitos dos casos, pessoas tornam-se reativas pois são impedidas de mudar por causa da estrutura social na qual estão inseridas, por interesses estabelecidos e situações convenientes, “(...) interesses e conveniências que são, se radicalmente analisados, interesses e conveniências do capital (e não do ser humano, que assim permanece um ator preso à mesmice imposta)" (CIAMPA, 2005, p. 165). Dessa forma, as atividades dos indivíduos identificados se tornam normatizadas, com vistas a manter a estrutura social, conservando as identidades produzidas. Identidades estas que poderiam ser entendidas como instrumentais.

Segundo a filosofia clássica e, particularmente, a filosofia aristotélica, no domínio social, o homem age como criatura que calcula, preocupa-se apenas com sua sobrevivência e os interesses práticos são o único critério para a ação. Nesse domínio, o homem não age por si mesmo, não possui vida política e, portanto, empreende práticas que não refletem quem ele realmente é. Na vida em sociedade, o homem age em relação à aprovação e à censura dos outros, sendo esse o padrão para desenvolver seu senso moral. Tal relativismo moral leva os indivíduos a se comportarem exclusivamente segundo a recompensa obtida no próprio reconhecimento dos outros como um comportamento adequado, correto e justo. O indivíduo perde então sua individualidade, sua identidade, para se tornar apenas uma criatura fluida, pronta para desempenhar papéis convenientes (MANNHEIM, 1986; RAMOS, 1981).

Nesse sentido, na sociedade moderna, ocorre o que Ramos (1981, p. 53) denomina de "fluidez da individualidade". O homem moderno se comporta de forma fluida e calculista, segundo regras objetivas de conveniência. Isso ocorreria devido à falta de um paradigma meta-histórico que ofereça referência para uma estrutura normativa da conduta humana. A sociedade capitalista moderna legitima-se a si mesma, como se fosse um contrato amplo entre seres humanos. Nesse sentido, é bom o que é útil socialmente. A crença se desloca da fé transcendental para a mão invisível da sociedade. Em tal situação, o indivíduo não possuiria piso firme para expressar/construir sua identidade. Nisso, o indivíduo se despersonaliza, vivendo apenas como um ator, que desempenha um papel determinado na estrutura. A identidade autêntica se perde, na medida em que o indivíduo internaliza padrões externos, exigidos pelos papéis. As relações interpessoais se resumem em gerência da impressão, em que as pessoas se enganam sistematicamente (GOFFMAN, 1975).

O cinismo e a ironia passaram a ser a moralidade cotidiana dos individuos na sociedade de massas. Nesse sentido, de um lado, têm-se a razão humana e a disciplina moral atuando na planificação e na responsabilidade e, de outro, têm-se a vontade da destruição, a irracionalidade, guardando a mesma dinâmica. Esse formato de ser humano, símbolo da desproporção entre desenvolvimento intelectual e espiritual, tem sido disseminado pelas mídias de massa (MANNHEIM, 1962).

O homem médio entrega parte de sua própria individualidade cultural a cada novo ato de integração num complexo de atividade funcionalmente racionalizado. Torna-se cada vez mais acostumado a ser levado pelos outros e gradualmente abandona sua própria interpretação dos acontecimentos pela interpretação que lhe é dada por outros (MANNHEIM, 1962, p. 69).

Tal processo levaria à forma mais íntima de racionalização funcional: a autorracionalização, ou seja, o controle sistemático dos impulsos de forma a planificar a vida em prol de um objetivo consciente e prédefinido. Sentindo-se parte de uma organização maior, o indivíduo preocupa-se em ajustar todas as ações, modos de conduta e controle dos impulsos segundo as funções específicas que lhes são determinadas. Quanto mais isolado, independente e autônomo se sente o indivíduo, menor a necessidade de autorracionalização. Na sociedade moderna, com seu alto estágio de desenvolvimento administrativo, os indivíduos têm suas funções específicas determinadas e sua própria vida segue um plano de carreira, que estabelece as ideias e os sentimentos que são permitidos ter, assim como o tempo de lazer (MANNHEIM, 1962). 
Nesse sentido, quando racionalizada predominantemente de forma instrumental, a identidade se torna um atributo meramente relacional, voltado apenas à aceitação do outro, à conformação aos padrões e papéis sociais. A identidade instrumental está relacionada intrisecamente à passividade do indivíduo e à ideia de impossibilidade de modificação das condições dadas, para que uma identidade autêntica pudesse ser afirmada. Em outras palavras, o indivíduo assume uma identidade instrumental quando pauta sua conduta a partir de sua existência imediata e não de sua transcendência.

Algumas teorias sobre a construção da identidade parecem sinalizar para a diferença entre os processos em que a identidade é construída a partir da existência e da transcendência, mas sem explicitar tais termos. No sentido da conformação do indivíduo à estrutura social, Dubar (2005) fala das estratégias identitárias internas, que visariam amenizar a tensão entre o que o indivíduo acredita ser e o que outros pensam que ele é. Nesse processo, o indivíduo tentaria assimilar o papel que lhe é imposto externamente a sua autoconcepção identitária, numa tentativa de conciliação com suas identificações anteriores e, ao mesmo tempo, numa tentativa de construção de uma nova identidade. Esse seria o mecanismo central de processos de socialização nos quais os indivíduos são moldados para pertencer a determinados meios sociais com regras e papéis bem definidos.

Nesse sentido, o conceito de identidade instrumental, ou seja, de uma identidade que é assumida pelo indivíduo em suas práticas como um meio para obter determinados fins, notadamente, aceitação e manutenção da existência, parece ser análogo ao conceito de "identidade social virtual", cunhado por Goffman (1975, p. 12) e utilizado por Dubar (2005). A identidade social virtual seria fruto da formação de rotulagens, a partir de preconcepções dos outros sobre o que o indivíduo é. Tais preconcepções se transformam em expectativas normativas, em exigências apresentadas de modo rigoroso. A partir disso, os outros imputariam precocemente um caráter ao indivíduo, como uma afirmativa do que ele deveria ser.

Com o intuito de ser aceito, o indivíduo então assumiria de forma instrumental a identidade que lhe é imposta. Esse processo é denominado por Dubar (2005) de atribuição. Ele ocorreria quando as pessoas são identificadas pelos outros, podendo ser incluídas numericamente em categorias pré-definidas ou ser classificadas genericamente como membros de um grupo ou classe. A atribuição da identidade, pelas instituições e pelos agentes externos, se produz a partir da formalização legítima dessas categorias, que se impõem temporariamente e coletivamente aos atores implicados. Dessa forma, o indivíduo estaria compelido a aceitar a identidade que lhe é atribuída, pois não veria possibilidade de modificação das categorias e nem de ir contra as estratégias das instituições e dos agentes externos. Ressalta-se, por isso, que se trata de uma identidade temporária, pois não representaria a essência do sujeito.

Analogamente, Tajfel (1981) descreve as situações em que ocorreriam estratégias identitárias do tipo instrumental. $\mathrm{O}$ indivíduo agiria pautado pela instrumentalidade quando deseja mudar de categoria social e percebe que pode fazer isso enquanto indivíduo isolado. Nesse caso, sua percepção sobre a sociedade estaria relacionada à crença na mobilidade social. $\mathrm{O}$ indivíduo acredita que os grupos sociais são flexíveis e permeáveis, sendo o movimento de um grupo para o outro livre e justo para todos. A crença na mobilidade social suscitaria, portanto, a aceitação da estrutura do sistema social vigente, resistência a mudanças radicais e, na esfera do trabalho, comprometimento com os objetivos estratégicos da instituição empregadora (TAJFEL, 1981). Em outras palavras, a afirmação de uma identidade instrumental estaria ligada à crença de que as condições de existência dadas são capazes de proporcionar satisfação e autorrealização. Caberia ao indivíduo apenas empreender práticas que seriam os meios para se atingir os fins desejados.

\section{Identidade substantiva}

Se por um lado, a identidade instrumental está relacionada à socialização, à crença na mobilidade social e aos papéis, a identidade substantiva estaria baseada nas conviç̧ões essenciais do indivíduo e na ideia de que o bom homem "nunca é um ser inteiramente socializado; é, antes, um ator sob tensão, cedendo ou resistindo 
aos estímulos sociais, com base em seu senso ético" (RAMOS, 1981, p. 52). Para Ramos (1981), embora a vida em sociedade demande o desempenho de um cargo ou função e, por conseguinte, certo grau de autorracionalização da conduta, o indivíduo age sempre orientado segundo sua concepção de mundo, seu ideal de realização própria e social, seus valores, os quais são indispensáveis para sua segurança e integridade interna. Contudo, ocasionalmente, tais convicções podem levar o indivíduo a conflitos e o tornar polêmico, caso venham de encontro às estratégias vigentes no contexto.

A conduta pautada por outro tipo de racionalidade sempre esteve presente na história do pensamento. Representa a possibilidade de libertação da repressão instaurada pela racionalidade instrumental, "o fim da dominação na satisfação" (MARCUSE, 1973, p. 161). Nesse sentido, ao se pautar pela racionalidade substantiva, o indivíduo se torna capaz de agir com inteligência e de construir julgamentos independentes, à base de uma percepção própria da interrelação entre os acontecimentos em determinada situação. Mannheim (1986) coloca que a industrialização crescente, verificada na sociedade moderna, implicou na expansão da racionalidade instrumental, contudo, não promoveu a racionalidade substancial. Tal processo culminou na privação dos indivíduos médios de reflexão, percepção e responsabilidade, sendo estas transferidas para os grupos dirigentes.

Apesar de não utilizar explicitamente o termo racionalidade, ao diferenciar labor, trabalho e ação, Arendt (2004) parece sinalizar para diferentes tipos de racionalidade que poderiam operar na vida humana. Enquanto labor e trabalho são atividades relacionadas à instrumentalidade, seja para manutenção da vida ou para fabricação da imortalidade humana por meio de um mundo artificial, a ação se relaciona à interação entre as pessoas e, dessa forma, à afirmação da pluralidade e imprevisibilidade humana, à vivência da vida política. Em outras palavras, para agir, o indivíduo necessitaria ser capaz de refletir, de assumir responsabilidades e de pensar de forma racionalmente substancial.

A capacidade de ação, em contraposição à mera existência corpórea, depende da iniciativa, mas trata-se de uma iniciativa da qual nenhum ser humano pode abster-se sem deixar de ser humano. Isto não ocorre com nenhuma outra atividade da vita activa. Para Arendt (2004), portanto, a vida humana sem ação é inconcebível, pois deixa de ser vivida entre homens, passaria a ser uma vida de autômatos previsíveis. Não haveria humanidade sem espaços para o exercício da racionalidade substancial e é somente a partir dela que os indivíduos são capazes de agir de forma singular e distinta. É a partir da ação, e dos sentidos que lhe são atribuídos (discurso), que o indivíduo revela sua identidade:

Na ação e no discurso, os homens mostram quem são, revelam ativamente suas identidades pessoais e singulares, e assim apresentam-se ao mundo humano, enquanto suas identidades físicas são reveladas, sem qualquer atividade própria, na conformação singular do corpo e no som singular da voz. Esta revelação de 'quem', em contraposição a 'o que' alguém é os dons, qualidades, talentos e defeitos que alguém pode exibir ou ocultar - está implícita em tudo o que se diz ou faz (ARENDT, 2004, p. 192).

Analogamente, é possível depreender a partir dos conceitos de Arendt (2004) que as condutas racionalmente substantivas revelam quem o indivíduo realmente é, revelam sua essência e sua singularidade. Em contrapartida, condutas racionalmente instrumentais revelam simplesmente o que o indivíduo é em um dado contexto, quais são suas funções, papéis, estigmas. Há, portanto, uma diferenciação entre a identidade substantiva, que seria autêntica, e a identidade instrumental, que seria situacional e condicionada pela sobrevivência e pela aceitação social.

O exercício da identidade substantiva viria à tona somente nos momentos em que as pessoas estão em interação, "no simples gozo da convivência humana, e não 'pró' ou 'contra' as outras. Embora ninguém saiba que tipo de 'quem' revela ao se expor na ação e na palavra, é necessário que cada um esteja disposto a correr o risco da revelação" (ARENDT, 2004, p. 192). Da mesma forma, Arendt (2004, p. 193) assevera que 
a conduta que não revela a identidade de seu agente, deixa de ser ação. Torna-se apenas um meio de se atingir um fim, instrumentaliza-se, "quer iludindo o inimigo, quer ofuscando a todos com propaganda":

Em tais situações, a ação perde a qualidade através da qual transcende a mera atividade produtiva que, desde a modesta fabricação de objetos de uso até a inspirada criação de obras de arte, é desprovida de outro significado além do que é claramente visível ao fim do processo de produção.

Outro autor que não trata explicitamente do tema da racionalidade, mas que também desenvolveu conceitos convergentes a essa perspectiva foi Ciampa (2005). Ele propõe o conceito de identidade metamorfose, uma identidade que se modificaria dialeticamente, unindo atividade, consciência e identidade.

Sem a inversão idealista (que vê o conceito criando a realidade), podemos aproximar a identidade do conceito, especialmente se considerarmos que para Hegel o conceito é pensamento e ser; surgem de uma mesma gênese, não como três coisas justapostas, mas presença de todos em cada um deles, numa unidade que é o sujeito (CIAMPA, 2005, p. 143).

"Sem essa unidade, a subjetividade é desejo que não se concretiza, e a objetividade é finalidade sem realização" (CIAMPA, 2005, p. 146). Ou seja, sem a unidade entre pensar e ser, a identidade se pauta pela racionalidade instrumental. O indivíduo abre mão da sua realização, do exercício da razão substantiva. Em contrapartida, quando o agir se torna uma atividade finalizada, que relaciona desejo e finalidade, torna-se possível a prática transformadora de si e do mundo. Nesse sentido, para Ciampa (2005), a formação de uma identidade que transcenda os níveis pessoal e social é indispensável para a emancipação do indivíduo, sendo a identidade metamorfose indispensável para sua autorrealização.

Ciampa (2005) descreve o processo de metamorfose da identidade da seguinte forma: quando o indivíduo nega as determinações sociais que o negam enquanto sujeito (negação da negação), ele se torna capaz de expressar um outro "outro" que também faz parte do seu eu, mas que não era representado nas relações sociais. Dessa forma, ocorre a alterização de sua identidade, por meio da eliminação da identidade pressuposta externamente (identidade instrumental ou identidade social virtual, segundo Goffman [1975]); do fim do processo constante de reposição social (adequação aos papéis); e por meio do desenvolvimento de uma identidade posta como metamorfose constante. Isso permite ao indivíduo se representar sempre como diferente de si mesmo (negando a representação cristalizada) e, assim, se tornar sujeito. Para Ciampa (2005, p. 182), a metamorfose da identidade “(...) ainda quando impedida, ainda quando oculta, expressa a invencibilidade da substância humana, como produção histórica e material". Expressa, nesse sentido, a capacidade de transcendência humana.

Tendo em vista o contexto do mundo social moderno, tornam-se cada vez mais raros os espaços para atividades substantivas e para exercício da identidade autêntica. Contudo, entende-se que o homem buscaria sempre diferentes táticas para superar sua alienação e manter sua própria condição humana. Mesmo que em uma situação extrema, em que o indivíduo opte por se anular e aceitar de forma passiva a conformidade a papéis situacionais, ele se viria recolhido dentro de si mesmo, afirmando uma identidade de sua própria criação e sem um centro ordenador da vida. Nesse sentido, a tentativa de adoção total da identidade instrumental não lograria suprimir a identidade substantiva, porém, poderia deformá-la numa identidade narcisista (RAMOS, 1981).

Outra forma de superação da instrumentalidade imposta pelo sistema social moderno é destacada por Dubar (2005) como estratégias identitárias externas, que se contrapõem às estratégias internas expostas no subitem anterior. Ambas estratégias, externas e internas, visariam amenizar a tensão entre o que se acredita ser e o que outros pensam que se é. Contudo, as transações identitárias externas ocorrem quando o indivíduo tenta convencer os outros significativos sobre o que ele realmente é. 
$\mathrm{O}$ indivíduo, nesse caso, assumiria uma identidade substantiva ou metamorfose, sentindo-se capaz de agir sobre o mundo de forma transformadora e reagindo contra a mera conformidade aos papéis. Nesse sentido, assume-se uma identidade política. Segundo Dubar (2005), quando os indivíduos rejeitam as identificações impostas externamente e preferem definir a si mesmo de outra forma, eles estariam empreendendo ações de pertencimento, as quais representariam o que o indivíduo quer ser substancialmente.

Portanto, o ato de pertencimento se difere intrisecamente do processo de atribuição, apresentado no subitem anterior. Apesar de ambos ocorrerem somente na interação social e de muitas vezes serem reduzidos a um mecanismo único pelas teorias sociológicas, Dubar (2005) coloca que esses dois processos são heterogêneos. O processo de atribuição da identidade, pelas instituições e pelos agentes externos, se produz a partir da formalização legítima de categorias, que se impõem temporariamente e coletivamente aos atores implicados. Já o pertencimento se refere a categorias e atributos que o indivíduo realmente acredita ou deseja possuir.

No processo de construção da identidade substantiva o indivíduo deve constituir sua identidade a partir, cronologicamente: das identidades sociais herdadas da geração anterior (conferida pelos pais); das identidades instrumentais conferidas pela socialização primária; e das identidades possíveis acessíveis pelas socializações secundárias. Por outro lado, as próprias categorias pertinentes de identificação social evoluem com o tempo e podem ser afetadas pelo processo de negociações identitárias (DUBAR, 2005).

A análise da identidade substantiva somente é possível por meio da compreensão das trajetórias individuais, nas quais os indivíduos constroem a história sobre o que são. Esse tipo de identidade também se baseia em categorias legítimas, para o indivíduo e para o grupo de referência, a partir do qual ele se constrói. Nota-se que nem sempre esse grupo de referência coincide com o grupo ao qual o indivíduo é enquadrado por outrem. Contudo, o que conta para a interiorização ativa da identidade é apenas a legitimação subjetiva do indivíduo (DUBAR, 2005).

A partir da teoria proposta por Dubar (2005), é possível compreender o processo de construção da identidade, como fruto da articulação entre os sistemas de ação, que propõem identidades instrumentais, e as narrativas de vida, que revelam as identificações às quais os indivíduos aderem ativamente, ou seja, revelam as identidades substantivas. A construção da identidade pode se dar tanto em movimentos de continuidade, entre os papéis impostos e as identidades, ou de ruptura entre os mesmos. Nesse sentido, as configurações identitárias são formas relativamente estáveis, mas sempre evolutivas, pois o indivíduo ao mesmo tempo é identificado e se identifica.

Entende-se, portanto, que a identidade é um atributo expresso na atividade humana, que se encontra inserida em um contexto de relações de poder. Os interesses dominantes determinam as estratégias vigentes em determinados espaços. Tais estratégias influenciam a conduta daqueles que se encontram sob seu controle. Quando se comportam segundo as regras sociais estabelecidas estrategicamente, os indivíduos estariam pautando sua conduta segundo uma racionalidade instrumental, que conduziria à aceitação de papéis externamente impostos e à afirmação de uma identidade instrumental, atingindo certos fins, como a própria sobrevivência. Em contrapartida, quando o indivíduo se vê capaz de agir autonomamente, ele veria possibilidade de mudança no sistema social, de forma a criar espaços onde é possível a afirmação de sua essência, sua identidade substantiva. Para isso, seria necessário que o indivíduo transcendesse suas condições imediatas de existência, para que ele se sentisse verdadeiramente livre para revelar quem ele é. Nesse estado, o indivíduo torna-se capaz de desenhar sua própria história, de se expressar enquanto ser único e distinto.

A discussão sobre identidade proposta neste ensaio pressupõe o ser humano como um ser integral. Contudo, em diferentes contextos, o indivíduo pauta sua conduta a partir de diferentes racionalidades. Sendo a realidade social multicêntrica, baseada em diferentes tipos de relações interpessoais, o indivíduo se esforçaria não na maximização da utilidade, mas na ordenação de sua existência de acordo com suas necessidades de atualização pessoal. Nesse sentido, coexistem espaços onde os valores de mercado imperam e espaços onde a relação é pautada pela racionalidade substantiva, pela atualização humana. Nos sistemas que visam a 
maximização da utilidade, a atualização pessoal raramente ocorre, sendo incidental. Da mesma forma, nos sistemas que visam a atualização pessoal, a maximização da utilidade também é incidental (RAMOS, 1981).

Nesse sentido, para a compreensão das racionalidades que estariam por trás das práticas individuais, é imprescindível o entendimento da racionalidade inerente aos próprios sistemas nos quais o indivíduo se insere ao longo de sua vida. Tais sistemas seriam espaços propícios a determinados tipos de racionalidades, que guiam o teor das relações interpessoais que nele ocorrem. A partir dessa constatação, propõe-se que o estudo da identidade envolva níveis coletivos de associação, aqui denominadas como identidades coletivas. Notadamente, no contexto organizacional, as identidades coletivas emergem enquanto grupos formalmente arquitetados pela estrutura da organização ou como agrupamentos espontâneos reconhecidos externamente como tais. $\mathrm{O}$ entendimento da racionalidade das identidades coletivas que se formam no interior das organizações é, portanto, crucial para se chegar ao entendimento da dinâmica das identidades individuais envolvidas.

\section{A Formação da Identidade Coletiva em Contextos Organizacionais}

Borzeix e Linhart (1996) ao retomar o conceito de identidade coletiva no trabalho afirmam que a identidade coletiva se constrói quando há mobilização social em prol de um denominador comum, legitimado por todos que compartilham da identidade coletiva. A identidade de grupos não seria única, mas sim variável de acordo com os interesses em jogo em determinada situação. Portanto, não se trata da perda da identidade coletiva na fase moderna do capitalismo. Trata-se de uma mudança nos processos identificatórios, determinados pela diversidade de interesses.

O termo identidade coletiva tem suas raízes em diversos conceitos sociológicos tradicionais, que vão desde a ideia de "consciência coletiva" de Durkheim até a questão da "consciência de classe" de Marx (HARDY, LAWRENCE e GRANT, 2005). Devido à variedade conceitual, o termo identidade coletiva tem sido utilizado em ocasiões diversas, resultando em confusão teórica. Como exemplos, a identidade coletiva tem sido empregada para explicar muitas dimensões e dinâmicas diferentes em fenômenos sociais: a predominância de categorias sociais entre os indivíduos, as representações públicas das categorias sociais, as definições partilhadas entre os membros de suas posições, o caráter expressivo de uma ação, a solidariedade nos movimentos sociais, fatores que motivam a participação em tais movimentos, entre outros (POLLETA e JASPER, 2001).

Para evitar a aplicação indiscriminada do conceito, Polletta e Jasper (2001) definem identidade coletiva como uma conexão cognitiva, moral e emocional do indivíduo com uma comunidade, categoria, prática ou instituição. É a percepção de status ou relação compartilhada, que pode ser imaginada simplesmente ou experienciada diretamente. A identidade coletiva é fluida e relacional, emergindo das interações com inúmeras audiências diferentes. Dessa forma, ela só ganha sentido a partir do momento em que é reconhecida pelos grupos externos como entidade culturalmente legítima (ROSCH, 1975; WRY, LOUNSBURY e GLYNN, 2011).

Hardy, Lawrence e Grant (2005) sugerem que as identidades coletivas são produzidas discursivamente, por meio de conversações, que criam realidades comuns para os membros. Elas seriam expressas em materiais culturais, nomes, narrativas, símbolos, estilos verbais, etc. A identidade se diferencia da ideologia, pois ela necessariamente implica em sentimentos positivos em relação aos membros do grupo. O desafio analítico desse campo de estudos é identificar as circunstâncias nas quais operam diferentes relações entre interesse e identidade, estratégia e identidade, política e identidade. Tais circunstâncias incluem processos culturais e também estruturais (POLLETTA e JASPER, 2001).

No interior das identidades coletivas, as próprias demandas identitárias podem ser vistas como estratégias de reivindicação ou as estratégias particulares podem ser associadas a identidades coletivas mais amplas. Assim, 
indivíduos podem se associar a identidades coletivas estrategicamente e suas escolhas estratégicas ganham sentido em relação aos grupos com os quais eles se identificam. Entretanto, é importante destacar que os grupos são necessariamente heterogêneos e as pessoas não se integram ao coletivo como se não tivessem história própria. Indivíduos podem expressar suas identidades de formas diferentes, dependendo da situação. Se eles representam o grupo em audiências públicas, eles podem se mostrar mais unidos e homogêneos, ao passo que, em uma reunião de membros, eles podem manifestar maiores discordâncias (POLLETTA e JASPER, 2001; BORZEIX e LINHART, 1996).

Ravasi e Rekom (2003), assim como Polletta e Jasper (2001), observam que há distinções sobre a questão de se estudar as identidades coletivas nas organizações: como a percepção ou expressão do que se é enquanto grupo; ou como as próprias práticas e estratégias implementadas pelo grupo no decorrer do tempo. Uma das abordagens possíveis para se contornar tal dicotomia é entender que a identidade coletiva e a identidade tática geralmente coincidem, pois os grupos incorporam as formas de ação. Para Ciampa (2005), conforme já exposto, a dicotomia entre percepção e ação é irreal no estudo da identidade já que a mesma se realiza na atividade humana. Nessa perspectiva, a compreensão de decisões táticas no interior de grupos, que revelam sua identidade coletiva, envolve a análise das diversas identidades, com saliências variadas, observando-se as práticas empreendidas no interior do grupo (POLLETTA e JASPER, 2001).

Considerando o estudo da identidade coletiva por meio das práticas, é possivel entendê-la como um conjunto de atores e práticas que são mais ou menos categorizados e compreendidos como definidores da identidade e também de atores divergentes que empreendem práticas variadas. Os atores e práticas que são percebidos como mais representativos da identidade coletiva seriam os protótipos dessa identidade. Esses atores se tornam peça fundamental para o reconhecimento externo da identidade coletiva e para a mobilização e coesão dos demais membros (ROSCH, 1975; WRY, LOUNSBURY e GLYNN, 2011).

O entendimento das identidades coletivas por meio dos protótipos implica na ideia de que elas são formadas por um núcleo de atores e práticas prototípicas e, também, à medida em que se afasta desse núcleo, por atores e práticas diversos até atingir o limite do que seria considerado um membro da identidade coletiva. $\mathrm{O}$ grau de dispersão e heterogeneidade dos membros em relaçao ao núcleo prototípico sinaliza o nível de ambiguidade e de saliência cultural da identidade coletiva em questão. Nesse sentido, o aumento do número de membros pela expansão dos limites de uma identidade coletiva pode ser positivo, pois confere maior notoriedade e reconhecimento externo à identidade e, ao mesmo tempo, pode ser negativo, pois pode descaracterizar as práticas consideradas prototípicas dessa identidade (ROSCH, 1975; WRY, LOUNSBURY e GLYNN, 2011).

As identidades coletivas, nesse sentido, seriam entidades necessariamente reconhecidas culturalmente. Contudo, elas não são grupos fechados e homogêneos de atores e práticas. São arenas dinâmicas em que novos membros trazem novos posicionamentos, membros antigos podem empreender inovações e os limites podem estar em constante negociação. Os atores e práticas considerados como protótipos da identidade funcionariam como "âncoras" que fornecem os pontos essenciais da identidade coletiva e a permitem funcionar como tal. Esses atores são normalmente os primeiros membros da identidade, os mais visíveis e/ou os de mais alto status social. Ancorados pelo protótipo, na esfera cotidiana, cada indivíduo integrante da identidade coletiva irá estabelecer suas práticas ao seu modo, segundo sua história de vida e sua identidade individual (ROSCH, 1975; WRY, LOUNSBURY e GLYNN, 2011).

Burity (1999) afirma que o tema da identidade é relevante para o estudo da sociedade contemporânea, pois ele trata diretamente da ambivalência humana, entre demandas por igualdade e uniformidade, de um lado, e por exclusividade e liberdade, de outro. O estudo da identidade em seus múltiplos níveis, pessoal e coletivo, permite apreender a complexidade da formação de um sistema social. Esse autor concebe a identidade coletiva como uma estratégia simbólica para lidar com o fluxo das experiências e sua ambivalência última, sendo indispensável a definição da concepção de um "nós" para o agir coletivo. Entretanto, tal definição deve estar em constante negociação, para se evitar que os sujeitos se apeguem à identidade coletiva como um dado imutável, natural e em constante ameaça de desvirtuamento e desrespeito por agentes externos. A 
questão da negociação da identidade é ressaltada nos novos movimentos sociais, como ONGs e fóruns. Da mesma forma, o chamado fundamentalismo das identidades também pode ser observado em movimentos e organizações mais conservadores. No primeiro caso, a tendência é o reconhecimento da pluralidade de identidades pessoais no interior do movimento, já no segundo, a tendência é a predominância de uma identidade comum para todos, por meio da tentativa de suprimir as diferenças.

A dinâmica de formação das identidades coletivas no interior das organizações perpassa, obviamente, o processo de construção de identidades individuais e da identidade da organização, enquanto um dos agrupamentos passíveis de se engendrar identificações e ações coletivas. Ciampa (2005, p. 150-151) aponta para a possibilidade teórico-empírica de se investigar a identidade em seu nível coletivo:

[...] ao estudar um ser humano, deve ficar claro que se está sempre estudando uma formação material determinada, qualquer que seja o corte feito na universalidade das relações recíprocas em que está inserido (o que autoriza, sem ilogicidade, por exemplo, falar tanto em identidade pessoal como em identidade(s) coletiva(s) no âmbito das ciências humanas).

Portanto, considerando que os conceitos de identidade e identificação individuais não são suficientes para abarcar toda a dinâmica da organização enquanto sistema social, o termo identidade coletiva torna-se relevante. Isso porque esse conceito permite ao pesquisador ir a campo com uma abordagem mais aberta à emergência de níveis identificatórios variados. Heracleous e Jacobs (2006) defendem que, numa perspectiva sócioconstrucionista, as organizações podem e devem ser estudadas em diferentes níveis, indo além dos níveis hierárquicos e formais. Os níveis de análise devem ser estabelecidos a partir do ponto de vista dos próprios sujeitos de pesquisa, por meio da coleta de dados e do raciocínio indutivo do pesquisador. Os variados níveis organizacionais, como indivíduos, grupos, departamentos e unidades, devem emergir dos discursos e das ações dos indivíduos pesquisados, como construções sociais, e não como delimitações $a$ priori da pesquisa.

A necessidade de se estudar as formações da identidade em seus vários níveis e as interrelações entre esses níveis tem sido destacada por estudiosos da área de identidade nas organizações como Ashforth e Mael (1989) e Ravasi e Rekom (2003). Para os primeiros, dado o argumento de que os indivíduos frequentemente possuem identificações sociais múltiplas (e conflituosas) no interior das organizações, pesquisas nessa área deveriam focar também em subgrupos emergentes, além da organização como um todo. O papel que a identificação social e o processo de comparação intergrupal possuem no conflito entre grupos poderia ser mais bem explorado por meio da análise das interações nos e entre grupos. Ravasi e Rekom (2003), por sua vez, afirmam que o termo identidade organizacional em si já pressupõe uma interface entre níveis analíticos micro e macro (individual, grupal, organizacional, interorganizacional, etc). Isso porque, ao se tratar de identidade organizacional, acaba-se mencionando aspectos da identidade individual, identidade no trabalho e identidade grupal, o que demonstra a complementaridade entre esses fenômenos.

Entendendo as organizações como sistemas sociais abertos, socialmente construídos, é possível afirmar que os indíviduos inseridos na estrutura organizacional poderiam se engajar em identidades coletivas, tanto em prol de sua mobilidade social, quanto em prol de mudanças (TAJFEL, 1981). Ou seja, indivíduos poderiam se engajar em identidades coletivas baseados em uma racionalidade instrumental ou substantiva.

No primeiro caso, a identidade coletiva tenderia a ser baseada em grupos formais de trabalho ou mesmo na organização como um todo. O comportamento do indivíduo, mesmo em grupo, tenderia a ser do tipo interpessoal, visando sua diferenciação dos demais e o alcance de objetivos individuais. Os grupos seriam, portanto, menos coesos e tenderiam à fragmentação devido à competitividade. $\mathrm{O}$ indivíduo visando a mobilidade social, dentro da organização, poderia também agir isoladamente de maneira informal, burlando normas e padrões estabelecidos. Já no caso de se almejar a mudança estrutural da organização, seriam formados grupos informais, crentes em ideias transcendentes à realidade imediata e, por isso, transgressores da ordem organizacional. Esses grupos tenderiam a ser mais coesos e baseados na colaboração. Dessa forma, 
originam-se as divergências entre identidades, tanto individuais quanto grupais, no interior das organizações, notadamente, naquelas de natureza econômica (TAJFEL, 1981).

Estudar a identidade nas organizações, considerando toda a complexidade do conceito, perpassa necessariamente pelo estudo da identidade em seus diversos níveis, conforme já exposto. Além disso, tornase imprescindível a compreensão das interrelações entre esses níveis; a dinâmica de formação das identidades coletivas; as racionalidades por detrás das condutas; as motivações individuais para se identificar e integrar a organização ou grupos no interior da organização; a forma como os grupos intraorganizacionais interagem entre si; as relações de poder entre grupos e entre pessoas; e a construção do significado da organização que emerge e se reconstrói a partir de todo o processo.

Com o intuito de abarcar as dinâmicas supracitadas e entendendo que a identidade nas organizações é construída a partir das práticas (discursivas) torna-se relevante compreender o processo de formação das estratégias e táticas organizacionais, grupais e individuais no interior da organização. As práticas no interior da organização seriam a materialização das identidades, assumindo significados específicos e contextuais e construindo dialeticamente essas mesmas identidades. No nível coletivo, tais práticas (identidades) poderiam ser apreendidas enquanto práticas mais ou menos compartilhadas pelos indivíduos, cujos significados, racionalidades e gêneros discursivos seriam também semelhantes entre esses indivíduos. Ademais, a identidade coletiva deve ter reconhecimento externo em seu contexto. Para distinguir as identidades coletivas formadas no interior de uma organização, portanto, necessariamente, há de se adentrar na esfera cotidiana, visando identificar quais grupos são reconhecidos e compreender o compartilhamento de práticas, significados e de racionalidades.

No item a seguir, empreendeu-se um esforço para se demonstrar como poderia se dar a operacionalização das análises das identidades construídas em um contexto organizacional, a partir dos construtos teóricos levantados.

\section{Uma Proposta para a Análise das Identidades em um Contexto Organizacional}

Sendo a identidade individual construída a partir das práticas discursivas e sendo estas últimas sempre relacionadas a estruturas sociolinguísticas e aos gêneros discursivos, a identidade individual é revelada em determinado contexto e em relação a outras identidades, individuais e coletivas. Entende-se, portanto, que as identidades coletivas seriam espaços onde operam certos gêneros de discurso, certos padrões de práticas enunciativas e, adicionalmente, certo tipo de racionalidade. Inserido em uma identidade coletiva, o indivíduo compartilha com os demais determinados significados e ações, sendo a racionalidade um elemento subjacente que fundamenta a própria razão de existência do grupo.

Conforme já exposto, o indivíduo pode se engajar em um coletivo baseado tanto em critérios instrumentais quanto substantivos, visando mobilidade social ou a mudança estrutural (TAJFEL, 1981). Também é necessário considerar a racionalidade inerente ao próprio grupo. Em certos momentos, podem coexistir tipos diferentes de racionalidade em uma mesma coletividade. Contudo, sempre tenderia a haver um tipo que é predominante e que sustenta a construção de sentidos e a expressão das identidades individuais nela inseridas (RAMOS, 1981).

Dessa forma, primeiramente, propõe-se a aplicação de procedimentos metodológicos da Análise do Discurso: como a identificação de percursos semânticos, isto é, conjuntos mais amplos de sentidos que ordenam as ideias centrais dos enunciados; a identificação de estratégias de persuasão por parte do enunciador, por exemplo, a seleção do vocabulário, o silenciamento de temas e figuras, o emprego de personagens discursivas e a relação entre temas explícitos e implícitos; e as relações de convergência e de divergência estabelecidas entre os níveis intra e interdiscursivo (FARIA, 2001; FARIA e LINHARES, 1993). A partir disso, deve-se diferenciar os elementos discursivos pertencentes aos indivíduos e os elementos 
compartilhados, relacionados às identidades coletivas. Após desvendar os aspectos implícitos que permeam os discursos, seria necessário extrair as racionalidades subjacentes, tanto dos indivíduos quanto dos coletivos. Com esse processo analítico, tornar-se-ia possível delinear as identidades construídas no interior do coletivo, assim como as tensões entre identidades individuais e coletivas.

Em suma, entende-se, que os espaços de interação delimitados pelas identidades coletivas operam por gêneros discursivos que limitam a expressão das identidades individuais. Contudo, ao mesmo tempo, o indivíduo teria oportunidades de fazer escolhas quanto às identidades coletivas que ele faria parte, assim como, a partir da capacidade de transcendência orientada pela racionalidade substantiva, poderia também transformar ativamente os espaços que lhe impõem relações de dominação.

Figura 3

\section{Articulação entre os níveis identitários e discursivos}

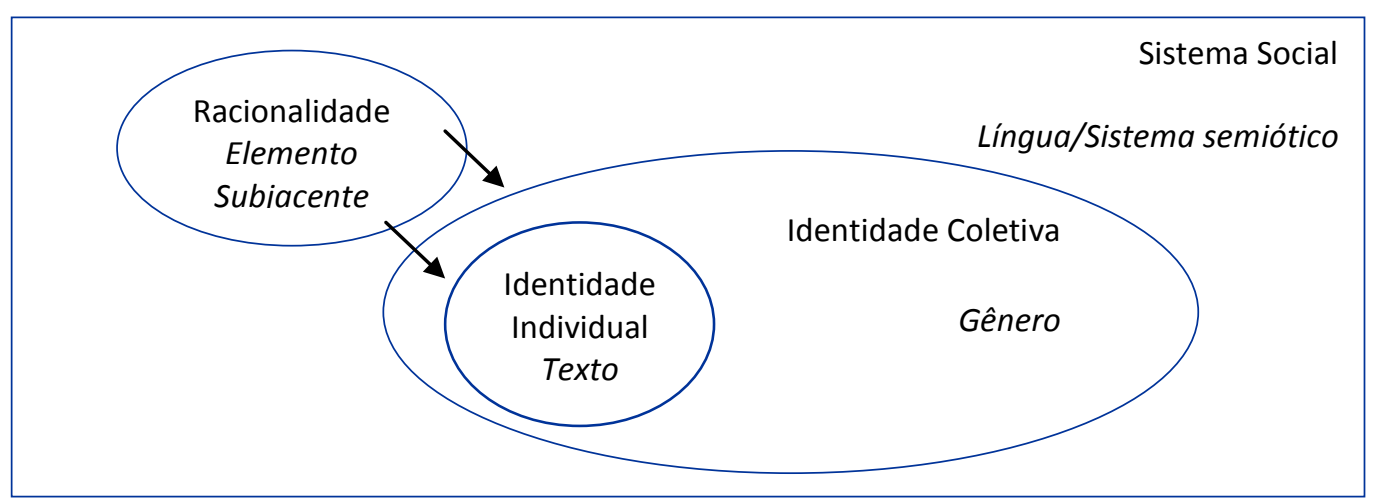

Fonte: Elaborado pelos autores.

Haveria, portanto, diferentes tipos de identidades coletivas, que variam segundo as possibilidades de expressão autêntica das identidades individuais. Esses tipos podem ser diferenciados, por exemplo, tomandose como base as categorias de Ramos (1981). O autor faz distinções entre categorias da vida humana, em que imperariam determinados padrões de conduta, gêneros discursivos e racionalidades. Essas categorias variam entre dois contínuos: orientação individual/comunitária e prescrição/ausência de normas. Nos extremos da ausência de normas, estão os estados de "Anomia" (individual) e "Motim" (comunitário). Quando há alta prescrição de normas e uma orientação comunitária, a convivência estaria pautada pela Economia. Em um contexto de mínima prescrição de normas e orientação comunitária, Ramos (1981) define a categoria "Isonomia". No caso de prescrição mínima de normas e orientação individual, tem-se a "Fenonomia".

O presente ensaio representou um esforço teórico-metodológico de se sistematizar de forma diferenciada a pesquisa em identidade nos contextos organizacionais, segundo o entendimento do indivíduo como ser integral e potencialmente autônomo. $\mathrm{O}$ estudo da identidade deve perpassar a análise discursiva das práticas cotidianas dos indivíduos, uma vez que a compreensão de quem o indivíduo é segue a interpretação dos sentidos de sua ação. A compreensão da ação não obedece necessariamente o ato verbal, senão também o discurso não-verbal. É necessário reconhecer, contudo, que o processo de interpretação dessas dimensões será sempre falho, pois perpassa inevitavelmente pela interpretação de um agente exterior, neste caso, do pesquisador. $\mathrm{O}$ pesquisador nunca será capaz de desvendar inteiramente a construção de sentidos do indivíduo no momento em que ele age e, assim, também não é capaz de apreender integralmente quais seriam as racionalidades envolvidas e sua identidade. No processo de análise discursiva/semiótica, o pesquisador irá apreender parcialmente os sentidos e a interpretação dos mesmos sofrerá interferências de sua própria subjetividade. 
A proposta deste artigo, portanto, é a visão integrativa baseada numa tríade de dimensões inseparáveis: identidade, discurso e prática (conforme figura 1). Ademais, agrega-se à proposta o fato de que tal tríade é sempre pautada por um tipo de racionalidade, imposto externamente ou exercido autonomamente. A partir disso, as articulações aqui expostas visam demonstrar a possibilidade de se estabelecer uma ligação coerente entre premissas ontologicamente críticas, baseadas em fundamentos filosóficos negativos, e procedimentos epistemológicos de base construtivo-interpretativa (REY, 2005). Além disso, entende-se que o esforço de se articular o estudo das identidades enquanto práticas discursivas, à metodologia da Análise do Discurso pode também trazer contribuições ao campo dos estudos sobre identidade nas organizações. Propõe-se iniciar a análise pelo nível textual, no qual as identidades individuais se revelaram, e depois identificar representações e práticas mais ou menos compartilhadas entre os indivíduos, indicando possíveis gêneros discursivos respectivos às identidades coletivas. Dessa forma, poderiam ser coerentemente empregadas diferentes correntes da Análise do Discurso, buscando evidenciar os mecanismos de construção de sentido em diferentes níveis.

\section{Referências}

ALBERT, S.; WHETTEN, D. A. Organizational identity. In: CUMMINGS, L. L.; STAW, B. M. (Orgs.). Research in organizational behavior, v. VII. Greenwich: Jay Press, 1985.

ARENDT, H. A condição humana. Rio de Janeiro: Forense Universitária, 2004.

ASHFORTH, B., MAEL, F. Social identity theory and the organization. Academy of Management Review, v. 14, n. 1, 1989.

BORZEIX, A.; LINHART, D. Identidades e práticas lingüísticas na empresa. In: CHANLAT, J. F. (Org.) O indivíduo na organização: dimensões esquecidas, v. III. São Paulo: Atlas, 1996.

BURITY, J. A. Identidade e cidadania: a cultura cívica no contexto de uma nova relação entre sociedade civil, indivíduos e estado. In: Cadernos de Estudos Sociais, v. 15, n. 2, jul.-dez.1999.

CALDAS, M. P.; WOOD JR., T. Identidade Organizacional. Revista de Administração de Empresas - RAE. São Paulo, v.37, n.1, jan./mar. 1997.

CARRIERI, A. de P.; PAUlA, A. P. P.; DAVEL, E. Identidade nas organizações: múltipla? fluida? autônoma? Organizações \& Sociedade, v. 15, n. 45, abr./jun.2008.

CERTEAU, M. de. A invenção do cotidiano: artes de fazer. Petrópolis: Vozes, 1994.

CIAMPA, A. C. Estória do Severino e a história da Severina. São Paulo: Brasiliense, 2005.

DUBAR, C. A socialização: construção das identidades sociais e profissionais. São Paulo: Martins Fontes, 2005.

FAIRCLOUGH, N. Analysing Discourse: textual analysis for social research. Londres: Routledge, 2003.

FARIA, A. A. M. Interdiscurso e intradiscurso: da teoria à metodologia. In: MENDES, E. A.e de M.; OLIVEIRA, P. M.; BENN-IBLER, V. (Org.). O novo milênio: interfaces lingüísticas e literárias. Belo Horizonte: FALE/UFMG, 2001.

.; LINHARES, P. T. S. O preço da passagem no discurso de uma empresa de ônibus. In: MACHADO, I. L. $\overline{\text { (Org.). }}$ Análises de discursos: sedução e persuasão. Cadernos de Pesquisa do NAPq. Belo Horizonte: FALE/UFMG/NAPq, n. 13, 1993.

FOUCAULT, M. História da sexualidade I: a vontade de saber. Rio de Janeiro: Edições Graal, 2006. 
. A arqueologia do saber. Rio de Janeiro: Forense Universitária, 2007.

GOFFMAN, E. Stigma: Notes on the Management of Spoiled Identity. Englewood Cliffs: Prentice Hall, 1975.

HALL, S. A identidade cultural na pós-modernidade. 8. ed. Rio de Janeiro: DP\&A, 2003.

HARDY, C; LAWRENCE, T. B.; GRANT, D. Discourse and collaboration: the role of conversations and collective identity. Academy of Management Review, v. 30, n. 1, 2005.

HERACLEOUS, L; JACOBS, C. An embodied metaphor view of organizational levels. In: INTERNATIONAL CONFERENCE ON ORGANIZATIONAL DISCOURSE: identity, ideology and idiosyncrasy, 7., 2006, Amsterdam. Anais... Amsterdam: Vrije University, 2006. 1 CD-ROM.

LIMA, S. M. M.; HOPFER, K. R.; LIMA-SOUZA, J. E. Complementaridade entre racionalidades na construção da identidade profissional. RAE-eletrônica, v. 3, n. 2, jul./dez. 2004.

MANNHEIM, K. O homem e a sociedade: estudos sobre a estrutura social moderna. Rio de Janeiro: Zahar, 1962. . Ideologia e Utopia. Rio de Janeiro: 1986.

MARCUSE, H. A ideologia da sociedade industrial. Rio de Janeiro: Zahar, 1973.

POLLETTA, F.; JASPER, J. M. Collective identity and social movements. Annual Review of Sociology, v. $27,2001$.

RAMOS, A. G. A Nova Ciência das Organizações: uma reconstrução da riqueza das nações. 2.ed. Rio de Janeiro: Editora da FGV, 1981.

RAVASI, D.; REKOM, J. V. Key Issues in Organizational Identity and Identification Theory. Corporate Reputation Review, v. 6, n. 2, 2003.

REY, F. G. Pesquisa qualitativa e subjetividade: os processos de construção da informação. São Paulo: Pioneira Thomson Learning, 2005.

ROSCH, E. Cognitive representations of semantic categories. Journal of Exp. Psychology, v. 104, p. 192-233, 1975.

SPINK, M. J.; MEDRADO, B. Produção de sentidos no cotidiano: uma abordagem teórico-metodológica para análise das práticas discursivas. In: SPINK, M. J. (Org.). Práticas discursivas e produção de sentidos no cotidiano: aproximações teóricas e metodológicas. São Paulo: Cortez, 1999.

TAJFEL, H. Human groups and social categories. Cambridge: Cambridge University Press, 1981.

WEBER, M. Economia e Sociedade: fundamentos da sociologia compreensiva. v. 1, 4 ed. São Paulo: Imprensa Oficial do Estado de São Paulo, 2004.

WOODWARD, K. Identidade e Diferença: uma construção teórica e conceitual. In: SILVA, T. T. (Org.) Identidade e Diferença: a perspectiva dos estudos culturais. Petrópolis: Vozes, 2000.

WRY, T.; LOUNSBURY, M.; GLYNN, M. Legitimating nascent collective identities: coordinating cultural entrepreneurship.Organization Science, v. 22, n. 2, mar./apr. 2011. 